Review

\title{
Extending in vitro digestion models to specific human populations: Perspectives, practical tools and bio-relevant information
}

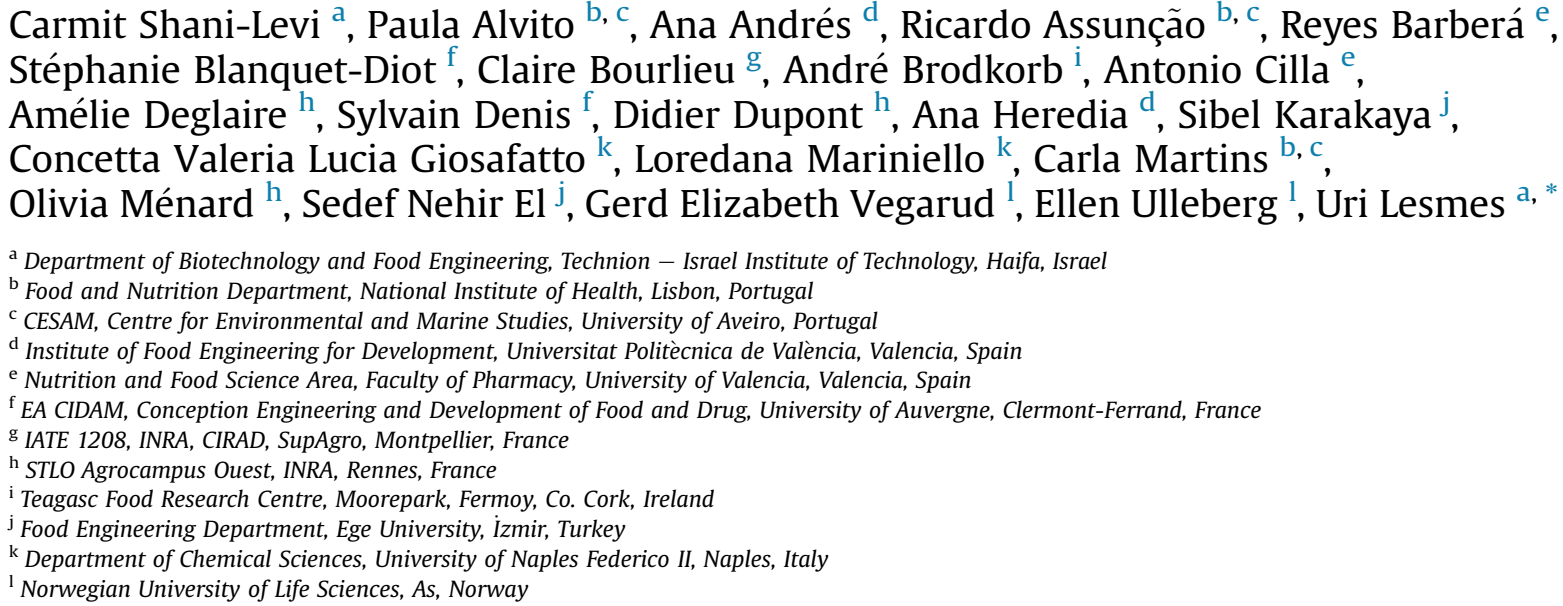

\section{A R T I C L E I N F O}

\section{Article history:}

Received 31 May 2016

Received in revised form

5 October 2016

Accepted 26 October 2016

Available online 9 November 2016

\section{Keywords:}

Food digestion

In vitro digestion

Gastric

Infants

Elderly

Gastro-intestinal disorders

\begin{abstract}
A B S T R A C T
Background: In vitro digestion models show great promise in facilitating the rationale design of foods. This paper provides a look into the current state of the art and outlines possible future paths for developments of digestion models recreating the diverse physiological conditions of specific groups of the human population.

Scope and approach: Based on a collective effort of experts, this paper outlines considerations and parameters needed for development of new in vitro digestion models, e.g. gastric $\mathrm{pH}$, enzymatic activities, gastric emptying rate and more. These and other parameters are detrimental to the adequate development of in vitro models that enable deeper insight into matters of food luminal breakdown as well as nutrient and nutraceutical bioaccessibility. Subsequently, we present an overview of some new and emerging in vitro digestion models mirroring the gastro-intestinal conditions of infants, the elderly and patients of cystic fibrosis or gastric bypass surgery.

Key findings and conclusions: This paper calls for synchronization, harmonization and validation of potential developments in in vitro digestion models that would greatly facilitate manufacturing of foods tailored or even personalized, to a certain extent, to various strata of the human population.
\end{abstract}

(c) 2016 Elsevier Ltd. All rights reserved.
Abbreviations: CF, Cystic Fibrosis; EFFoST, European Federation of Food Science and Technology; GBP, Gastric Bypass; GI, Gastrointestinal; GIT, Gastrointestinal tract; IBD, inflammatory bowel disease; IVD, In vitro digestion; PTL, Pancreatic Triglyceride Lipase; SG, Sleeve Gastrectomy.

* Corresponding author. Laboratory of Chemistry of Foods and Bioactives, Department of Biotechnology and Food Engineering, Technion - Israel Institute of Technology, Haifa, 32000, Israel.

E-mail address: lesmesu@bfe.technion.ac.il (U. Lesmes).

\section{Introduction}

\subsection{In vitro models for food research}

In vitro digestion (IVD) modelling is a vivid field of research that shows great promise in facilitating the development of foods and oral formulations based on better understanding of their digestive fate in the stomach and small intestine in as well as downstream 
ramifications to the gut microbiome (Bornhorst, Gouseti, Wickham, \& Bakalis, 2016; Guerra et al., 2012; Hur, Lim, Decker, \& McClements, 2011; Payne, Zihler, Chassard, \& Lacroix, 2012). Although human or in vivo animal studies are still considered a "gold standard" for tackling issues of bioaccessibility, absorption, bioavailability, metabolism and excretion, IVD methods have the advantage of being more rapid, less labor intensive and having significantly less bioethical restrictions. In fact, various IVD models have been increasingly applied to assess the digestive fate and potential toxicity of ingested natural and engineered nano-materials (Lefebvre et al., 2015). This has led to great variability in scientific efforts, including some contradicting studies, and stimulated the recent effort of the INFOGEST network of scientists to develop a consensus harmonized static in vitro digestion model based on physiologically relevant conditions gathered from humans (Minekus et al., 2014). This harmonized protocol was validated in a wide inter-laboratory trial (Egger et al., 2016) and is currently pending on-going efforts to correlate findings of protein digestibility with an in vivo trial in pigs and biochemical assays with human aspirates (yet to be published). However, these and other numerous scientific publications focus on IVD systems designed for evaluating the digestive fate of foods and oral formulations in the adult alimentary canal.

During a dedicated workshop held by the European Federation of Food Science and Technology (EFFoST) in Athens on November 2015, we found that current physiological literature offers professionals additional opportunities to recreate the unique and specific gastro-intestinal (GI) functions of other human populations, such as infants, the elderly and more. Such intriguing possibilities would open new opportunities to study and develop foods and oral formulations better tailored to the needs of such specific populations. Based on the pooled and accumulated experience of the INFOGEST network, it was decided to help a systematic and responsible orchestration of relevant global efforts, maximize synergisms between researchers and harmonize efforts to develop new IVD models. Thus, this paper provides a look into the current state of the art and paves possible future paths for developments, all with the aim of ensuring adequate and fruitful endeavors and outputs to the food and health community.

\subsection{Current status of adult in vitro digestion (IVD) models}

In vitro digestion models were initially developed to serve as research tools to characterize and clarify the structural and biochemical changes of food components under physiological conditions, caused by alimentary enzymes (Romano et al., 2016), GI motility and by the colonic microbiota. In principle, IVD models of the upper GI need to overcome the shortcomings of in vivo trials (i.e. ethical constraints, low throughput, control over subjects and reproducibility) and account for the most bio-relevant anatomical and physiological considerations mirroring the mouth, stomach, small and large intestine lumen and gut lining. In fact and in spite of their limitations, IVD models are particularly suited for investigating the luminal physiochemical changes in food, matters of bioaccessibility and some aspects of bioavailability.

Historically, efforts to develop IVD models began in the early 1990 's with pioneering works to develop reliable, robust, reproducible and bio-relevant tools like the multi-compartmental GI model developed by TNO in the Netherlands (Minekus, Marteau, Havenaar, \& Huisintveld, 1995) or the three stage continuous fermentation systems recreating the human colon (Macfarlane, Macfarlane, \& Gibson, 1998; Molly, Woestyne, \& Verstraete, 1993). Since, the field has boomed with numerous IVD models, ranging from simple static mono-compartmental models to computer-controlled multi-compartmental dynamic IVD models, as reviewed by others (Glahn, Wien, VanCampen, \& Miller, 1996; Guerra et al., 2012; Hur et al., 2011; McClements \& Li, 2010; Payne et al., 2012; Yoo \& Chen, 2006). Recent studies even raised the possibility of using human GI aspirates in IVD models (Ulleberg et al., 2011) or coupling IVD models with human cell cultures of Caco-2 epithelial cells or Caco-2 co-cultures with HT-29 mucus producing cells (Deat et al., 2009; Vors et al., 2012). Yet, the low accessibility and stability of human aspirates and the complexity of coupling IVD research with cell cultures, challenge the wide spread use of highly bio-relevant alternatives over simple protocols currently used in IVD models. Further, in vitro cell culture systems have been coupled to some IVD models to enable investigating questions of cellular uptake and brush border enzymatic breakdown, which better elucidate the bioavailability of specific substances (Deat et al., 2009; Manione et al., 2015; Vors et al., 2012).

Concomitantly, various efforts reported to develop and apply sophisticated IVD models that are intended to be more realistic, encompassing various aspects of digestion dynamics (e.g. physiological acid secretion and gastric emptying), mass transport phenomena (i.e. absorption and diffusion) and rheological aspects (i.e. mixing) (Blanquet et al., 2004; Dekkers, Kolodziejczyk, Acquistapace, Engmann, \& Wooster, 2016; Kong \& Singh, 2010a; Levi \& Lesmes, 2014; Mercuri, Lo Curto, Wickham, Craig, \& Barker, 2008; Shani-Levi, Levi-Tal, \& Lesmes, 2013; Tharakan, Norton, Fryer, \& Bakalis, 2010; Yoo \& Chen, 2006). To date, both advanced and simple IVD models have be used to investigate a variety of systems. Examples include investigations of simple high purity protein solutions, multi-component model systems like emulsions and even more real foods, like dairy gels and pasta. These and other investigations have significantly advanced our understanding of the interplay between food ingredients, food products and the alimentary canal of healthy adults. Such insights include not just understanding of food breakdown but also its impact on gastro-intestinal functions, e.g. gastric emptying and intestinal motility, as detailed by others (Grundy et al., 2016; Houghton, Hickson, \& Read, 1987; Meyer, Elashoff, \& Lake, 1999; Sarosiek et al., 2010).

\subsubsection{Identified research needs}

Despite the various hectic activity in the field of understanding food's digestion in adults, there is still much room for further advancements and breaching of current gaps in knowledge and capabilities. The various discussions held during the Athens workshop identified that amongst future advancements in the field, research should include efforts: [I] To improve the biorelevance of luminal composition and dynamics (e.g. $\mathrm{pH}$ profiles and use of gastric lipases); [II] To validate and/or correlate IVD data with in vivo findings; [III] To recreate the 3D micro-architecture of the intestinal lining and mucosa through co-cultures (e.g. Caco-2 and HT29 cell lines, grown on various scaffolds); and [IV] To develop predictive in silico models. All of these topics were enthusiastically discussed in separate work groups during the workshop and are expected to bring up further scientific publications.

\subsection{Rationale and approach for extending IVD models}

Advancements in the field of food science and technology need to address numerous challenges that humanity is and will be facing in the 21st century (Floros et al., 2010). These challenges will include feeding the growing and ageing world population, better and sustainable use of natural resources as well as improving our ability to exploit foods' potential to prevent diseases and maintain health promote wellness. In this respect, personalized or tailored nutrition seem highly promising and challenging strategies (Joost 
et al., 2007; Qi, 2014; Zeevi et al., 2015). Such endeavors will require bridging manufacturing capabilities and product engineering to meet the specific needs of the consumer. Based on the demonstrated success in the field of infant formula development, IVD models harbor great potential to facilitate relevant developments of foods tailored to thespecific GI capabilities of specific human starta such as elderly people, pregnant women, patients of various Inflammatory Bowel Diseases (IBD) and even diabetics.

Thus, this paper outlines the considerations and parameters needed for development of new IVD models as well as an overview of some of the new and emerging IVD models and the relevant physiological information, all with the aim of stimulating adequate and fruitful endeavors and outputs to the food and health community. Adapting the consensus INFOGEST protocol scheme, a basic static model is suggested to comprise of an oral, gastric and intestinal phase (Minekus et al., 2014). Each phase should address the composition of the relevant simulated fluid (ionic and enzymatic composition), the time of processing and the nature of the bolus/ chyme (liquid, semi-solid or solid and dilution ratio with the bodily secretions). The selection of the quantitative aspects for the operational parameters should rely on information gathered from the most relevant human studies with good statistical power (i.e. avoiding studies with less than 10 subjects as a rule of thumb). In circumstances where no human data can be found, developers should either make their best effort to rationally approximate the values or attempt to determine them directly as a part of a human trial. Thus, any new IVD model should clearly define its parameters, justify their selection and support it with relevant references.

\section{Practical considerations for developing IVD models}

Human GI physiology is a complicated semi-continuous set of bioreactors that are intertwined with the hematological, hormonal and nervous systems and change during life (Johnson, 2007; Remond et al., 2015; Tortora \& Derrickson, 2011). This highly complex nature of the GI limits the ability to recreate its entire functions in an in vitro model. However, many aspects of luminal digestion can be mirrored in IVD models using reliable and detailed information on the digestive system that can be found in the scientific literature. Therefore, it is imperative to understand the limitations of each model and ensure they do not collide with the research hypotheses. To this end, it is also imperative to be aware of and address the key anatomical and physiological parameters of the relevant GI organs.

The process of food digestion is an orchestrated series of bioprocessing operations that involve the breakdown of food, the release of nutrients, their uptake or downstream fermentation before their ultimate removal from the body through defecation. During digestion in the upper GI, food structure is broken down in the mouth, stomach and small intestine through complex reactions and interactions involving chemical and mechanical processes (Ferrua \& Singh, 2010; Johnson, 2007; Sensoy, 2014). Therefore, the following section discuss the most critical physiological parameters that are essential for in vitro digestion models.

\subsection{Oral phase}

Oral processing involves mastication and mechanical breakdown of food into a soft mass, termed bolus which is a mixture of processed food and saliva (DeSesso \& Jacobson, 2001). This short phase is detrimental to the sensorial perception of food and can be viewed as a coarse mechanical processing step with little chemical changes (Aken, Vingerhoeds, \& Wijk, 2011; van Vliet, van Aken, de Jongh, \& Hamer, 2009). This first step of digestion involves mixing food with salivary fluid that contains about $99 \%$ water in addition to various electrolytes and proteins, including enzymes such as amylase (Aps \& Martens, 2005; Rantonen, 2003). Saliva is continuously secreted into the oral cavity by parasympathetic control. While resting, the flow rate is about $0.5 \mathrm{ml} / \mathrm{min}$; but upon stimulation, the secretion increases 3 to 4 - fold with maximal flow rates of $10 \mathrm{ml} / \mathrm{min}$ (Guyton, 1991). Healthy adults will produce 500-1500 ml saliva per day (Aps \& Martens, 2005). Salivary fluid composition depends on the flow rate: at higher flow rates, sodium, calcium, chloride, bicarbonate, amylase increase while phosphate and mucin concentrations decrease, and the potassium concentrations show little change. Salivary $\mathrm{pH}$ values also fluctuate between fasted to fed state with values of 6.2-7.4 to 7.4-7.6, respectively (Versantvoort, Van de Kamp, \& Rompelberg, 2004). The key salivary enzyme is $\alpha$-amylase that hydrolyzes starch and related $\alpha$-(1,4)-linked polysaccharides (Nagler \& Hershkovich, 2005; Shern, Fox, \& Li, 1993). Mucin is also an important component of saliva with studies indicating it to induce emulsion flocculation (Sarkar, Goh, \& Singh, 2010, 2009; Singh \& Ye, 2013; Vingerhoeds, Silletti, de Groot, Schipper, \& van Aken, 2009). Yet, commercial mucins are partially hydrolyzed mixtures of mammalian mucins which limit their bio-relevance when applied in IVD models. In addition, there is some debate on the possible existence and activity of lingual lipase with a report indicating lingual lipase is active between $\mathrm{pH} 2-6.4$, indicating that this enzyme is active from the mouth to the small intestine (Hamosh, 1994).

\subsection{Gastric phase}

Following bolus formation in the oral phase, the stomach further processes the bolus into a semi-solid chyme within four distinct regions: cardiac, fundic, body and the pyloric regions (Ferrua \& Singh, 2010; Kong \& Singh, 2010b). Gastric juice comprises of hydrochloric acid, enzymes (pepsin and gastric lipase), various electrolytes, mucus, intrinsic factor and hormones with approximately $2 \mathrm{~L}$ of gastric juice secreted daily and $0.7 \mathrm{~L}$ secreted after a typical meal (Kopf-Bolanz et al., 2012; Seeley, Stephens, \& Tate, 1992). Parietal cells lining the stomach wall are responsible for the secretion of hydrochloric acid into the gastric lumen and bicarbonate into the bloodstream. The activity of these cells is responsible for the unique $\mathrm{pH}$ of the stomach which dynamically changes during digestion from 1.5 to 2.0 in the fasted state to 3.0-7.0 in the fed state. Gastric acidity induces protein denaturation and precipitation, hydrolytic reactions (e.g. breakdown of starch) and significantly reduces bacterial counts in the gastric lumen. The postprandial $\mathrm{pH}$ rise in the stomach is attributed to the buffering capacity of the ingested food and the Parietal cells generate a $\mathrm{pH}$ gradient that over the course of time reverts luminal $\mathrm{pH}$ back to the fasted state values. The $\mathrm{pH}$ profiles depend on age and clinical conditions of the consumer (Table 1) and can have various ramifications to the properties of ingested food systems, such as emulsions and gels (Dekkers et al., 2016; Shani-Levi et al., 2013). Gastric lipolysis and proteolysis are tightly linked (Guyton, 1991; Sams, Paume, Giallo, \& Carriere, 2016). The key gastric proteolytic enzyme, pepsin, is activated from its precursor pepsinogen (secreted by chief cells) via acid hydrolysis. The activated enzyme, which is also equated with commercial porcine pepsin, has a wide range of activity with optimal activity at $\mathrm{pH} 2$ and inactivate just above pH 6.5 (Johnston, Dettmar, Bishwokarma, Lively, \& Koufman, 2007). Pepsin is a non-specific protease and therefore hydrolyses itself (a reaction termed auto-pepsinolysis) and other enzymes present in the lumen. Another gastric enzyme is gastric lipase which is also activated by the acidic environment in the stomach (Sams et al., 2016). Gastric lipase presents $s n-3$ regiospecificity thus it hydrolyses triglycerides into sn-1,2diglycerides and one free fatty acid, pancreatic triglyceride lipase colipase dependent which is $s n$ - 
Table 1

Physiological characterization of human gastro-intestinal fluids.

\begin{tabular}{|c|c|c|c|}
\hline & Fasted & Fed & Suggested references \\
\hline \multicolumn{4}{|l|}{ Oral phase } \\
\hline $\mathrm{pH}$ & $6 ; 6.2-7.4$ & $7 ; 7.4-7.6$ & Guyton, 1991; Versantvoort, 2004 \\
\hline Fluid output & $0.5 \mathrm{~mL} / \mathrm{h}$ & $10 \mathrm{~mL}$ per meal & Guyton, 1991 \\
\hline Amylase & $45.6-49.6(\mathrm{U} / \mathrm{mL})$ & $43.7-47.5(\mathrm{U} / \mathrm{mL})$ & Neyraud, 2012 \\
\hline Lipase & $0.60-0.68(\mathrm{U} / \mathrm{mL})$ & $0.27-0.39(\mathrm{U} / \mathrm{mL})$ & Neyraud, 2012 \\
\hline Transit time of meal & - & $10 \mathrm{sec}-2 \mathrm{~min}$ & Guerra, 2012 \\
\hline \multicolumn{4}{|l|}{ Gastric phase } \\
\hline $\mathrm{pH}$ & $1.5-2.0$ & $3.0-7.0$ & Roberts, 2006; Malagelada, 1976 \\
\hline Fluid output & $1-85 \mathrm{~mL}$ & $238 \mathrm{~mL}$ & Roberts, 2006; Hunt, 1951 \\
\hline Pepsin & $0-8335(\mathrm{U} / \mathrm{mL})$ & $22,000-24,000(\mathrm{U} / \mathrm{mL})$ & Janowitz, 1952; Hunt, 1951 \\
\hline Gastric lipase & $120-130(\mathrm{U} / \mathrm{mL})$ & & Sams, 2016 \\
\hline Transit time of meal & - & $15 \mathrm{~min}-3 \mathrm{~h}$ & Guerra, 2012 \\
\hline \multicolumn{4}{|l|}{ Small intestine } \\
\hline $\mathrm{pH}$ & $5.4-6.5$ & $5.5-7.5$ & Dressman 1990; Ekmekcioglu 2002 \\
\hline Bicarbonate sectretion & $15-27 \mathrm{mM} / \mathrm{h}$ & & Ogden, 1993 \\
\hline \multirow[t]{3}{*}{ Total fluid output } & $118 \mathrm{~mL} / \mathrm{h}$ & $9000 \mathrm{~mL} / 24 \mathrm{~h}($ Mean $5250 \mathrm{~mL})$ & Ekmekcioglu, 2002 \\
\hline & $20-160 \mathrm{~mL}$ & $60-320 \mathrm{~mL} / 3-4 \mathrm{~h}$ & Gotch, 1957 \\
\hline & & $200-300 \mathrm{~mL} / 4 \mathrm{~h}$ & Ogden, 1993 \\
\hline Total proteolytic activity & $5.6-25.4 \mathrm{U} / \mathrm{mL}$ & & Ulleberg, 2011; Krogdahl \& Holm, 1979 \\
\hline Trypsin output & & $50-100-500 \mathrm{U} / \mathrm{mL}$ & Keller \& Layer, 2005 \\
\hline Trypsin activity & & $33-77 \mathrm{IU} / \mathrm{mL}$ & Braganza, 1978 \\
\hline Chymotrypsin output & & $70-150 \mathrm{U} / \mathrm{Kg}$ bodyweight/15 $\mathrm{min}$ & Holtmann, 1996 \\
\hline Amylase output & & $500-1000(\mathrm{U} / \mathrm{mL})$ & Keller \& Layer, 2005 \\
\hline Amylase activity & & $97-450(\mathrm{IU} / \mathrm{mL})$ & Braganza, 1978 \\
\hline Lipase output & & $3000-6000(\mathrm{U} / \mathrm{ml})$ & Keller \& Layer, 2005 \\
\hline \multirow[t]{2}{*}{ Lipase activity } & & $100-400(\mathrm{IU} / \mathrm{ml})$ & Keller \& Layer, 2005 \\
\hline & & $234-524(\mathrm{IU} / \mathrm{ml})$ & Braganza, 1978 \\
\hline \multirow[t]{3}{*}{ Bile $\left(\mathrm{TDC}^{\mathrm{a}}, \mathrm{GC}^{\mathrm{b}}, \mathrm{GCDC}^{\mathrm{c}}, \mathrm{GDC}^{\mathrm{d}}\right)$} & $1-4.5 \mathrm{mM}$ & & Ulleberg, 2011 \\
\hline & & $5.8-39 \mathrm{uM} / \mathrm{ml}$ & Fausa, 1974 \\
\hline & & $2.2-11.2 \mathrm{mM}$ & \\
\hline Surface tension & $32.3 \mathrm{mN} / \mathrm{m}$ & $28 \mathrm{mN} / \mathrm{m}$ & Kalantzi, 2006 \\
\hline Transit time & & $2-5 \mathrm{~h}$ & Kalantzi, 2006 \\
\hline \multicolumn{4}{|l|}{ Large intestine } \\
\hline $\mathrm{pH}$ & & $6.4-7.0$ & Evans, 1988 \\
\hline Bacterial load & & $1 \times 10^{11}-10^{12} \mathrm{CFU} / \mathrm{g}$ material & Evans, 1988 \\
\hline Short chain fatty acids & & $125-139 \mathrm{mM}$ & Cummings, 1987 \\
\hline Total fluid volume & & $187 \mathrm{~mL}$ & Cummings, 1990 \\
\hline Transit time & & $12-24 \mathrm{~h}$ & Guerra, 2012 \\
\hline
\end{tabular}

a Taurodeoxycholate.

b Glycocholate.

c Glycochenodeoxycholate.

d Glycodeoxycholate.

1,3 regioselective lipase (Miled et al., 2000). However, commercial gastric lipase is hard to find and is currently neglected in many IVD models, thought it initiates lipolysis and release free fatty acids which activate pancreatic triglyceride lipase.

The pyloric sphincter controls gastric emptying into the small intestine and is affected by three major factors: volume of the meal, its osmotic pressure and caloric content. Approximately $2 \mathrm{kcal} / \mathrm{per}$ minute are delivered through the pylorus to the duodenum (Campbell, 2015; Sams et al., 2016). Furthermore, gastric emptying has been well described by the Elashoff equation (Elashoff, Reedy, \& Meyer, 1982).

\subsection{Small intestinal phase}

Gastric chyme is gradually emptied into the small intestine, where most of the chemical breakdown and absorption occur mediated by auxiliary secretions of the liver, gall bladder, pancreas and intestinal epithelia. Chyme entering from the stomach to the small intestine are neutralized using bicarbonate and the $\mathrm{pH}$ increases from 2 to 6.2 in the duodenum, which is the first segment of the small intestine (Kalantzi et al., 2006). The main degradation of food starts in the duodenum into which about $1.2-1.5 \mathrm{~L}$ of pancreatic juice is secreted daily (Johnson, 2007). The jejunum and ileum are the later sections of the small intestine where digestion and absorption are completed before indigested fractions are pushed into the colon. Due to the anatomical complexity of the small intestine one cannot easily find data on food digestion in these segments. The pancreatic juice contains a mixture of enzymes, proenzymes, protease inhibitors, sodium bicarbonate and other electrolytes that are secreted in parallel and gradually over the course of 3-4 h, depending on the meal ingested. The pancreatic secretions contain a variety of enzymes in their proenzyme forms and include protrypsin, prochymotrypsin, proelastase, procarboxypeptidases, pancreatic lipase and $\alpha$-amylase in addition to ribonuclease and deoxyribonuclease (Boivin, Lanspa, Zinsmeister, Go, \& Dimagno, 1990; Keller \& Layer, 2005). Currently, IVD models make use of ill-defined mixtures of pancreatin or concoct enzyme mixtures mainly containing trypsin and $\alpha$ chymotrypsin. Every day, the human liver produces about $0.6-1.0 \mathrm{~L}$ of bile, which are stored in the gallbladder (Seeley et al., 1992). Bile acids are steroid acids composed mainly from taurocholic acid, glycocholic acid, taurochenodeoxycholic acid and glycochenodeoxycholic acid which are equal in concentration (Hofmann, 1999). In addition to enzymes delivered into the lumen, enzymes located in the epithelial brush border contribute to the further digestion of food. The brush border enzymes include glycosidases (dextrinase, glucoamylase), peptidases (aminopeptidase, carboxypeptidase, dipeptidase) and phophatases (Holmes \& Lobley, 1989). Altogether, the functions of the auxiliary organs in the fasted and fed conditions are stimuli responsive and are mainly affected by the 
composition of the ingested meal and the physical state of the consumer. Unfortunately, a wide range of enzyme outputs and activities (units) are reported due to different focus of the studies; type of diet (calories), specific nutrient (lipid, carbohydrate, protein or minerals) or non-nutrients (pharmaceuticals, drugs etc.) and physical properties of the meal (Armand et al., 1996; O'Keefe et al., 2003). Further, there are inconsistencies in data on the pancreatic enzyme activities due to the differences in biochemical assays used to characterize these secretions: ranging from use of natural or synthetic standards such as casein, BAEE, TAME, BTEE, measurement modes (potentiometric, colorimetric, spectrophotometric), calculation methods up to the definition of enzymatic units of activity. Examples for values found in literature are summarized in Table 1. Mechanically, the small intestine has a segmented nature of pushing chyme further down the GI and this segmentation motion was recently shown to be critical for luminal mixing and mass transfer (Tharakan et al., 2010).

As denoted, the small intestine is the major site of absorption of small molecules, which can occur passively through diffusion or actively through various transporter systems in the gut wall (Johnson, 2007). Further processing of materials can then take place within epithelia, e.g. lipid packing into chylomicrons. Transit time through the small intestine varies according to the diet caloric density; the rheological/mechanical properties (e.g. viscosity or gelling) and with consumer parameters, such as age and health (e.g. $2 \mathrm{~h}$ for healthy adult and $3 \mathrm{~h}$ for infant (Blanquet et al., 2004)).

\subsection{Large intestinal phase}

Undigested and un-absorbed foodstuffs and bodily secretions transit into the large intestine through the ileocecal valve. In this last part of the human GI tract, water and electrolytes are reabsorbed and bacterial fermentation of fiber and un-digestible food components occurs before bulk material is excreted (Moran \& Jackson, 1992). The colon is increasingly recognized for its milieu of bacteria, fungi, protozoa and archaea and rich metabolic activity equated to that of the human liver (Nardone \& Malfertheiner, 2011; O'Hara \& Shanahan, 2006; Olszewska \& Jagusztyn-Krynicka, 2012; Turnbaugh et al., 2007). Recent studies of the human colon microbiome have established various links between nutrition, the microbiome and health with evidence that microbiomes are affected by age, gender, diet, culture, geography and various physiological/pathological states (Albenberg \& Wu, 2014; D'Argenio et al., 2013; Flint, 2012; Holscher et al., 2015; Olszewska \& Jagusztyn-Krynicka, 2012). Therefore, it is no surprise that the field of IVD models of the human colon are also a vibrant field, as reviewed by others (Payne et al., 2012). In essence, the colon hosts immense bacterial counts in three distinct loci: the proximal, transverse and distal colon, which vary in their steady state $\mathrm{pH}$ with values of $5.8,6.2$ and 6.8 , respectively with transit times of $12-36 \mathrm{~h}$. Metabolically, the microbiome is highly active with both glycolytic and proteolytic activities noted and about $90 \%$ of fermented indigestible polysaccharides being metabolized into short-chain fatty acids. In addition, the mucosa lining of the colon is a major site for passive absorption of small metabolites and close interactions with the immune system (Clemente, Ursell, Parfrey, \& Knight, 2012).

\section{IVD models for specific populations}

\subsection{Infants}

The functionality of human gastro intestinal tract (GIT) develops in the first year of life with newborns ( $<28$ days of life) and infants up to six months possessing an immature digestive system compared to older infants ( $>6$ months) or the fully mature GI of an adult (Fig. 1). Moreover, prematurity affects strongly the digestive capabilities, with decreased GI functionality in preterm babies compared to full-term newborns (Bruce, 2012; Kelly \& Coutts, 2000; Kelly \& Newell, 1994; Ménard, Monfils, \& Tremblay, 1995). In fact, there are various differences between infants and adults mainly in some digestive enzymes and a relatively elevated gastric pH (3.5-6.5), as exhaustively reviewed (Abrahamse et al., 2012; Bourlieu et al., 2014; Nguyen, Bhandari, Cichero, \& Prakash, 2015b, 2015a). Briefly, infant digestion process neglects oral phase due to liquid meals rapidly transiting through the oral cavity (5-10 s). Small stomach storage capacity, affecting meal frequency, transit and volume, increases quickly during the first month of life from 10 to $20 \mathrm{~mL}$ up to $90-150 \mathrm{~mL}$ per meal (Abrahamse et al., 2012; Bourlieu et al., 2014). Infant fasting gastric pH is less acidic than of an adult (respectively $4-5$ vs. 2 in the fasted state) which may change gastric proteolysis, as optimal activity of pepsin is 1.5-2.2 (Henderson, Hamosh, Armand, Mehta, \& Hamosh, 1998; LiChan \& Nakai, 1989; Schlamowitz \& Peterson, 1959). Reduced pepsin secretion in newborns, $10-20 \%$ from adult levels, is another physiological reason explaining the limited gastric proteolysis (15\%) reported for infants (Bourlieu et al., 2014; Dupont et al., 2010a; 2010b; Romano, Giosafatto, Masi, \& Mariniello, 2015). Pepsin secretion increases with postnatal age and is more immature in preterm infants (Guyton, 1991).

In respect to intestinal digestion, proteolysis in infants has similar $\mathrm{pH}$ and trypsin concentrations as those in the intestine of adults, whereas chymotrypsins and carboxypeptidases-B just account for about $10 \%-60 \%$ of the activity found in adults (Edginton \& Fotaki, 2010; Lebenthal \& Lee, 1980). Regarding lipid digestion, gastric lipase activity and output are similar in preterm (Roman et al., 2007), full-term infants and adults (Armand et al., 1996; Sarles, Moreau, \& Verger, 1992). However, pancreatic lipases do vary between infants and adults with pancreatic triglyceride lipase (PTL) being the dominant intestinal lipolytic enzyme in adults while PTL-related protein 2 and bile salt-stimulated lipase are the key lipases in infants (Lindquist \& Hernell, 2010). In light of the high fat diet of infants (Hamosh, 2006), human breast milk contains endogenous lipase (bile salt-stimulated lipase mainly, 3.6-5.3 U/ $\mathrm{mL}$ of milk) that compensates for the low amount of pancreatic lipases (5-10\% the concentration found in adults) and low concentration of bile salts (50\% of adult values) (Lebenthal, Lee, \& Heitlinger, 1983). Regarding carbohydrate digestion, scarce data suggest low values of pancreatic amylase are found in the GI of infants aged less than 6 months. Thus, carbohydrate digestion in infants is believed to be highly facilitated by ingested salivary $\alpha$ amylase (at birth average of $10 \%$ of the adult level but highly variable (Christian, Edwards, \& Weaver, 1999; Sevenhuysen, Holodinsky, \& Dawes, 1984)) or mammary $\alpha$-amylase. In addition, reports also indicate the infant GI performs carbohydrate digestion through lactase, sucrose-isomaltase and glucoamylase (with activities of $\sim 50 \%$ above that of adults) (Bourlieu et al., 2014; Nguyen, et al., 2015a).

Another important step in infant GI maturation is colonic colonization of the infant gut with microbiota, which begins at birth and is an important player in the maturation and education of the immune system. Development of the infant microbiota is characterized by rapid and large changes in microbial abundance, diversity and composition, until around 3 years of age when the microbiota becomes adult-like (Matamoros, Gras-Leguen, Le Vacon, Potel, \& de La Cochetiere, 2013). Introduction of solid foods into the infant diet leads to a marked shift in microbial composition with an increase in clostridial species and a decrease in Bifidobacterium and Enterobacteriaceae. Many factors may influence the development of the gut microbiota in infants, such as mode of 


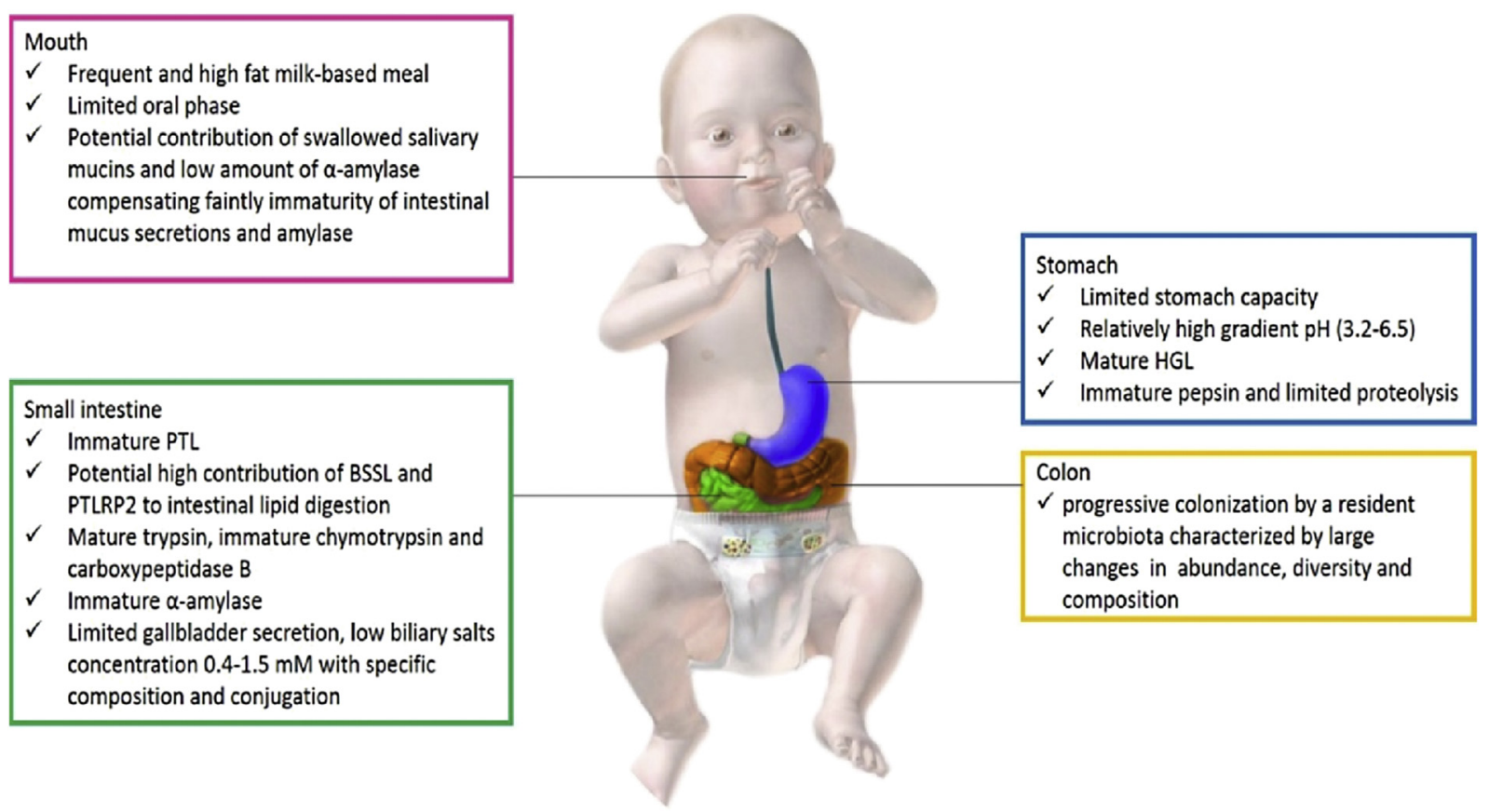

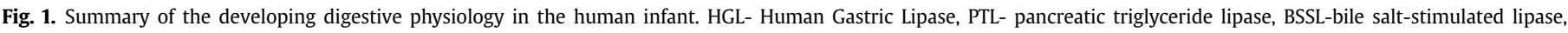
PTLRP2- pancreatic triglyceride lipase-related protein 2.

delivery, type of maternal diet, geographical location and consumption of antibiotics (Arrieta, Stiemsma, Amenyogbe, Brown, \& Finlay, 2014).

Based on the current physiological knowledge of the infant GI, various static and dynamic IVD models have been applied by researchers (Blanquet et al., 2004; de Oliveira et al., 2015; Dupont et al., 2010a; 2010b; Roussel et al., 2016; Shani-Levi et al., 2013). Yet, the development of a harmonized static infant IVD is needed. One of the most formidable challenges in this respect is the clear definition of the consumer being recreated since digestive parameters are highly affected by gestational and postnatal age. For instance preterm newborns compared to full-terms of same age have higher gastric $\mathrm{pH}$ resulting from more frequent feeding, lower pepsin activity (10\% of adult activity at four weeks vs. $30 \%$ in fullterms), faster gastric emptying, more limited gallbladder contraction index, lower concentration of electrolytes in pancreatic fluid, no amylase secretion and lower global pancreatic activity (Bourlieu et al., 2014).

To date, several studies have depicted static infant IVD models applied for studying various aspects of protein and lipid digestion. These various models are summarized in Table 2. As can be noted, various discrepancies are found in these models and include discrepancies in gastric $\mathrm{pH}$, ill-defined enzymatic proteolytic activity of enzymes and large variance in experimental duration. For example, the enzyme activity was most of the time not checked experimentally or based on the supplier's general characteristics, which hampered experiment replication in other laboratory. After an estimation of the pepsin units per $\mathrm{mL}$ of milk, a very large range of values was observed, ranging from 4 to $18563 \mathrm{U} / \mathrm{mL}$ of milk (Table 2). An in vivo study by Armand et al. (1996) reported an average postprandial value of $63 \mathrm{U} / \mathrm{mL}$ of gastric content $/ \mathrm{kg}$ of bodyweight of preterm infants, which would correspond to $425 \mathrm{U} /$ $\mathrm{mL}$ of milk for a term newborn of $4.25 \mathrm{~kg}$ and a meal to secretion ratio of $63: 37 \mathrm{v} / \mathrm{v}$. In respect to the intestinal phase, $\mathrm{pH}$ was homogeneous (6.5-7.5), but duration varied largely from 5 to $120 \mathrm{~min}$ and the meal proportion in the total volume varied from 25 up to
76\%. After an estimation of pancreatin content within each model, a factor of 30 between the maximum and the minimum values was found across models, which remains lower than that for pepsin (a 4500 fold difference). Bile salts, arising from a porcine or bovine bile extract or from purified bile salts, were estimated to vary by a factor of 10 across models.

In all models presented in Table 2, no clear definition of the infant stage was given, except for Fogleman, Cohen, Sakamoto, and Allen (2012), who aimed to mimic preterm infant digestion. Further, there are some dynamic IVD models described in recent literature (Blanquet et al., 2004; Havenaar et al., 2013; Ménard et al., 1995; Menard et al., 2014; de Oliveira et al., 2015; Roussel et al., 2016; Shani-Levi et al., 2013). In essence, these models try to recreate some of the dynamic aspects of digestion, e.g. gastric $\mathrm{pH}$ profiles post meal ingestion and gastric emptying rates. One of these has even been validated against in vivo data of proteolysis kinetics obtained in piglets (Menard et al., 2014). The TIM model developed by TNO (Netherlands) was adapted to simulate the GI of newborns, infants and toddlers $(0-1,1-6$, and 6-24 months of age, respectively) after ingestion of various types of food (formula milk, milk and cereals) and validated for these three age groups against published pharmacokinetic data on paracetamol (Havenaar et al., 2013). However, in this study, not all GI parameters applied to this commercial IVD model have been made publicly available. The same model has been very recently adapted to mimic, based on in vivo data, the gastric and small intestinal conditions of infant from 6 months to 2 years (Roussel et al., 2016). Some dynamic colonic models have also been developed (Cinquin, Le Blay, Fliss, \& Lacroix, 2004; Cinquin, Le Blay, Fliss, \& Lacroix, 2006a, 2006b). The composition and diversity of the bacterial community, as well as its metabolism, was found to be well correlated with those found in vivo in infant feces.

Altogether, infant IVD models are increasing in their applicability to food research, however, the variances and discrepancies found in current infant IVD model call for future efforts to better define a simple, harmonized and consensus infant static IVD model, 
Table 2

Literature review of the proposed in vitro static models for infant gastro-intestinal digestion ${ }^{\text {a }}$.

\begin{tabular}{|c|c|c|c|c|c|c|c|c|c|c|c|c|c|c|}
\hline \multirow[t]{2}{*}{ References } & \multirow[t]{2}{*}{ Meal } & \multicolumn{7}{|c|}{ Gastric phase } & \multicolumn{6}{|c|}{ Intestinal phase } \\
\hline & & $\overline{\mathrm{pH}}$ & $\begin{array}{l}\text { Duration } \\
\text { (min) }\end{array}$ & $\begin{array}{l}\text { Meal: } \\
\text { secretion } \\
\text { ratio }(\mathrm{v} / \mathrm{v})\end{array}$ & $\begin{array}{l}\text { Lipase content (/mL } \\
\text { of meal) }\end{array}$ & Pepsin ${ }^{\mathrm{b}}$ content & $\begin{array}{l}\text { Pepsin }^{\mathrm{c}}(\mathrm{U} / \mathrm{mL} \\
\text { of meal) }\end{array}$ & $\begin{array}{l}\text { Molar ratio } \\
\text { pepsin / } \\
\text { meal }\end{array}$ & $\overline{\mathrm{pH}}$ & $\begin{array}{l}\text { Duration } \\
\text { (min) }\end{array}$ & $\begin{array}{l}\text { Meal: } \\
\text { secretion } \\
\text { ratio }(\mathrm{v} / \mathrm{v})\end{array}$ & Enzyme(s) used $^{\mathrm{c}}$ & $\begin{array}{l}\text { Pancreatin } \\
\text { equivalent }(\mathrm{mg} / \\
\mathrm{mL} \text { of meal) }\end{array}$ & $\begin{array}{l}\text { Bile }^{\mathrm{d}} \\
(\mathrm{mg} / \mathrm{mL} \\
\text { of meal) }\end{array}$ \\
\hline $\begin{array}{l}\text { Chatterton et } \\
\text { al., } 2004\end{array}$ & $\begin{array}{l}\text { Human } \\
\text { milk }\end{array}$ & $\begin{array}{l}2,3,3.5 \\
4,5 \text { or } \\
6.5\end{array}$ & & 99:1 & $\begin{array}{l}\text { Supernatant of } \\
\text { gastric juice from } 2 \\
\text { neonates }\end{array}$ & - & - & & & & & no duodenal phase & & \\
\hline $\begin{array}{l}\text { Dupont et al., } \\
\text { 2010a }\end{array}$ & $\begin{array}{l}\text { Purified } \\
\text { proteins }\end{array}$ & 3 & 60 & $85: 15$ & - & $\begin{array}{l}22.75 \mathrm{U} / \mathrm{mg} \text { of } \\
\text { protein }\end{array}$ & $273^{\mathrm{f}}$ & 0.0042 & & 530 & $76: 24$ & $\begin{array}{l}\text { Porcine trypsin: } 3.45 \mathrm{U} / \mathrm{mg} \text { of } \\
\text { protein Bovine chymotrypsin: } 0.04 \\
\mathrm{U} / \mathrm{mg} \text { of protein }\end{array}$ & $5.91^{\mathrm{fh}}$ & $1.32^{\mathrm{i}}$ \\
\hline $\begin{array}{l}\text { Fogleman et } \\
\text { al., } 2012\end{array}$ & $\begin{array}{l}\text { Human } \\
\text { milk }\end{array}$ & 5 & 120 & $66: 34$ & $42.5 \mathrm{mg}$ & $\begin{array}{l}2.5 \mathrm{mg} / \mathrm{ml} \text { of } \\
\text { milk }\end{array}$ & 7500 & 0.3317 & 7 & 120 & $40: 60$ & Pancreatin: $2 \mathrm{mg} / \mathrm{mL}$ of SDF ${ }^{g}$ & 0.63 & 3.75 \\
\hline $\begin{array}{l}\text { Lueamsaisuk } \\
\text { et al., } 2014\end{array}$ & $\begin{array}{l}\text { Infant } \\
\text { formula }\end{array}$ & $\begin{array}{l}2,3.5 \\
4.5 \text { or }\end{array}$ & 120 & $20: 50$ & $\begin{array}{l}40 \mathrm{U} \text { (Rhizopus } \\
\text { Oryzae lipase) }\end{array}$ & $\begin{array}{l}4.5 \mathrm{mg} / \mathrm{ml} \text { of } \\
\mathrm{SGF}^{\mathrm{e}}(800-2500\end{array}$ & 18563 & 0.2829 & & & & No duodenal phase & & \\
\hline $\begin{array}{l}\text { Lueamsaisuk } \\
\text { et al., } 2015\end{array}$ & & 5.5 & & & & $\mathrm{U} / \mathrm{mg}$ ) & & & & & & & & \\
\hline $\begin{array}{l}\text { Prakash et al., } \\
2014\end{array}$ & $\begin{array}{l}\text { Infant } \\
\text { formula }\end{array}$ & 1.5 & 60 & $50: 50$ & - & $\begin{array}{l}3.2 \mathrm{mg} / \mathrm{ml} \text { of } \\
\text { SGF }\end{array}$ & 9600 & 0.1463 & 7 & 120 & $25: 75$ & Pancreatin: $1.6 \mathrm{mg} / \mathrm{ml}$ of digesta & 3.20 & 10.00 \\
\hline $\begin{array}{l}\text { Wada \& } \\
\text { Lonnerdal, } \\
\text { 2014, } 2015\end{array}$ & $\begin{array}{l}\text { Defatted } \\
\text { bovine milk }\end{array}$ & 4 & 15 & - & - & $\begin{array}{l}0.08 \mathrm{mg} / \mathrm{mg} \text { of } \\
\text { protein }\end{array}$ & $2880^{\mathrm{f}}$ & 0.0200 & 7 & 5 & - & Pancreatin: protein ratio of $1: 62.5$ & $0.19^{\mathrm{f}}$ & - \\
\hline $\begin{array}{l}\text { Dall'Asta et al., } \\
2015\end{array}$ & $\begin{array}{l}\text { Human } \\
\text { milk }\end{array}$ & 4.5 & 35 & $15: 9$ & - & $\begin{array}{l}0.013 \mathrm{mg} / \mathrm{ml} \text { of } \\
\text { milk }\end{array}$ & 4.0 & 0.0001 & 7.5 & 5120 & $15: 20$ & Porcine pancreatin: $9 \mathrm{mg} / \mathrm{mL}$ of SDF & 3.60 & $\begin{array}{l}6.00 \\
\text { (bovine } \\
\text { bile) }\end{array}$ \\
\hline $\begin{array}{l}\text { N-Guyen } \\
\text { Nguyen et } \\
\text { al., } 2015^{\mathrm{a}}\end{array}$ & $\begin{array}{l}\text { Infant } \\
\text { formula }\end{array}$ & 4 & & & & & $\begin{array}{l}\text { as detailed for } \\
\text { Dupont et al., } \\
2010\end{array}$ & & & & & & & \\
\hline Liu et al., 2016 & $\begin{array}{l}\text { Milk } \\
\text { protein } \\
\text { concentrate }\end{array}$ & 3 & 60 & $50: 50$ & - & $\begin{array}{l}113.8 \mathrm{U} / \mathrm{ml} \text { of } \\
\text { SGF }\end{array}$ & 113.8 & 0.0008 & 6.5 & 560 & $25: 75$ & Bovine trypsin: $8.6 \mathrm{U} / \mathrm{ml}$ of SDF & $2.46^{\mathrm{h}}$ & $4.00^{\mathrm{i}}$ \\
\hline
\end{tabular}

a Digestions were all conducted at $37^{\circ} \mathrm{C}$.

b Unless otherwise stated, pepsin originated from a porcine source.

c When pepsin activity was unknown, an activity of $3000 \mathrm{U} / \mathrm{mg}$ was considered.

d Enzyme origin mentioned when available.

e Simulated Gastric Fluid.

A protein concentration of $12 \mathrm{mg} / \mathrm{mL}$ of infant formula or milk was considered.

g Simulated Duodenal Fluid.

A trypsin activity of $7 \mathrm{U} / \mathrm{mg}$ of pancreatin was considered.

${ }^{\mathrm{i}}$ A content of $1 \mathrm{mmol}$ of bile salts / $\mathrm{g}$ of bile was considered 
such as that obtained for an adult IVD model (Minekus et al., 2014) as well as sophisticated dynamic IVD models. All of these should be developed with a rationale similar to that applied by the infant formula industry, i.e. focusing on specific and defined target populations such as stage one for $0-3$ months, stage 2 for $3-6$ months etc.

\subsection{Elderly}

Elderly nutrition, pharmacology and overall health care have been identified as one of the rising global challenges (UN, 2013). Ageing is typically accompanied by a milieu of changes including substantiated alterations and deterioration of gut functions, such as secretion of digestive fluids and enzymes, saliva, GIT contractions and chyme passage rates (Di Francesco et al., 2005; Feldman, Cryer, McArthur, Huet, \& Lee, 1996; Laugier, Bernard, Berthezene, \& Dupuy, 1991; Nagler \& Hershkovich, 2005; Russell et al., 1993; Salles, 2007; Vellas et al., 1988). Due to the irreversible nature of the changes in GIT functions, there is a growing need to deepen our understanding of foods' digestive fate in the elderly GI. This would facilitate rational design of foods to accommodate elderly physiological capabilities, improve nutrient bioaccessibility and bioavailability and help combat elderly malnutrition. Despite comprehensive knowledge on the GI deterioration with age and its ramifications to elderly malnutrition (Remond et al., 2015), there are scant IVD models of the elderly GI found in literature. One most recent study assessed the antioxidant capacity of a milk protein matrix in aged women, both in vitro and in vivo (Power-Grant et al., 2016). However, the target population of the study focused solely on women in the ages of 50-70. In relation to IVD models recreating elderly digestive conditions, two recent studies have been identified to apply in vivo data to the modelling parameters (Denis et al., 2016; Levi \& Lesmes, 2014). The first reports the set-up of a dynamic gastro-intestinal elderly ( $>70$ years old) model based on commercial bioreactors with details on all the parameters used and the rationale of their selection (Levi \& Lesmes, 2014). The second, reports an adaptation of the TNO gastrointestinal model (TIM) to the specific digestive conditions of the elderly ( $>65$ years old) and is used to study meat protein dynamic digestion (Denis et al., 2016). A summary of the digestive conditions applied in these models are given in Fig. 2, also summarizes conditions of the elderly population at the colon. Similar to the field of infant IVD modelling, elderly digestion models require not only harmonization but also validation and clearer definition of the elderly being studied.

\subsection{Developing IVDs for humans with GI disorders}

In light of the centrality of the GI system in human health and disease, various studies present information on human GI disorders. These are defined as diseases and/or conditions that interfere with the intake, digestion, and/or absorption of nutrients, causing various clinical symptoms and are broadly defined as maldigestion. Physiologically, the spectrum and underlying causes of GI disorders is immense from such conditions causing discomfort (e.g. lactose malabsorption) to those compromising health (e.g. pancreatic insufficiency in cystic fibrosis patients). All in all, these conditions arise from altered GI functions which lead to various effects on the disintegration, breakdown and uptake of nutrients and consequently on health (Högenhauer and Hammer, 2010). Some common factors that interfere with food digestion and related disorders, infections and surgical procedures linked to them are summarized in Table 3. In respect to food breakdown and bioaccessibility, many of the situations described may be mirrored using IVD models, as such conditions have been found to arise from variance and abnormalities in digestive parameters such as changes in gastric/intestinal $\mathrm{pH}$, secretion of digestive juices and transit times. Other disorders such as food allergies, autoimmune disorders (celiac sprue), Crohn's disease, obesity or diabetes are linked to interferences with the absorption and/or metabolism of nutrients from the food (Nolan, Johnston, \& Walters, 2012), hence IVD models for such conditions require much more sophistication in their in vitro recreation, if at all feasible. Yet, efforts to develop IVD models for specific strata of the population would offer useful tools not only in the development of new tailored foods but also improving relevant nutritional guidelines.

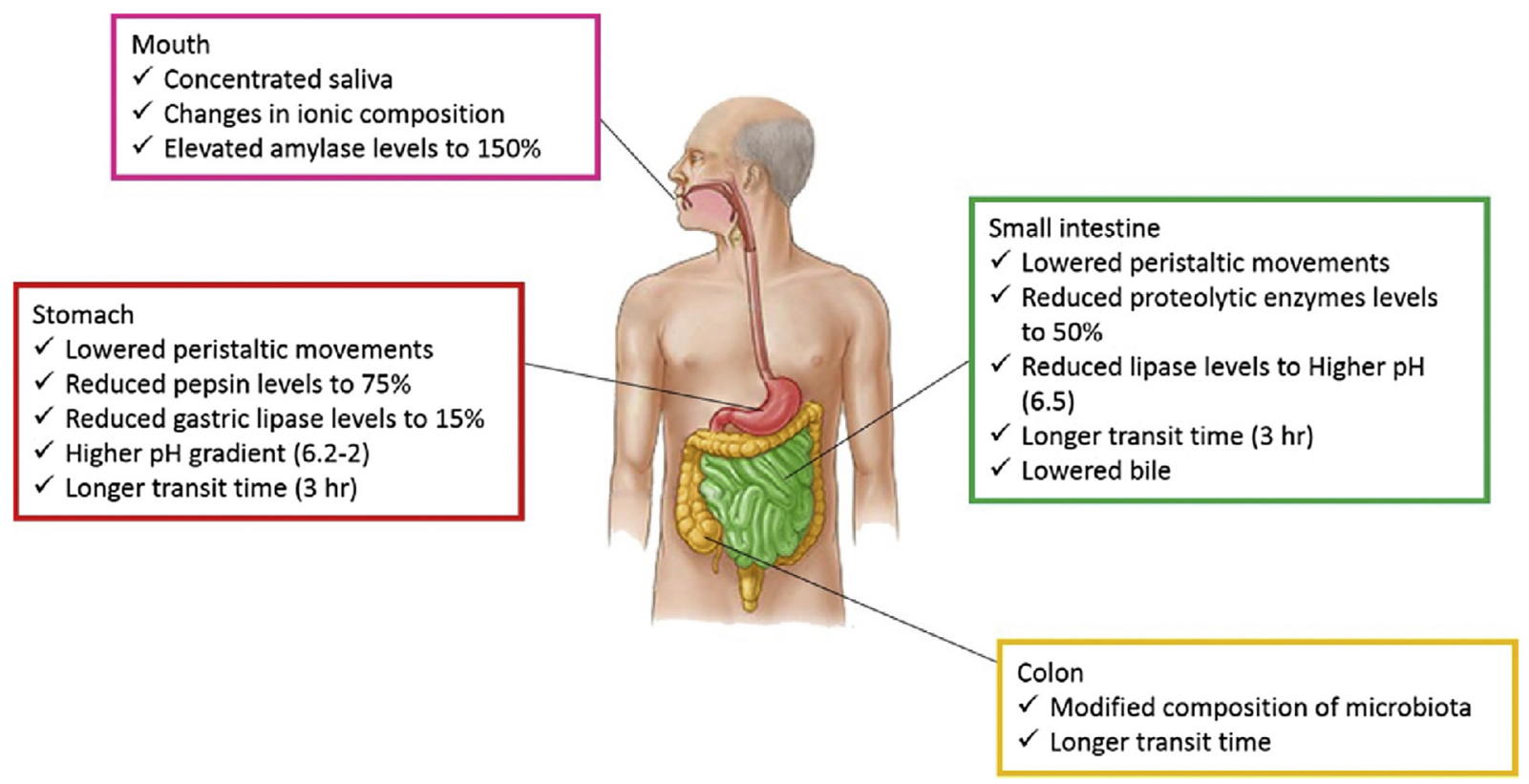

Fig. 2. Summary of the developing digestive physiology in the elderly. 
Table 3

Factors interfering with food digestion and related disorders.

\begin{tabular}{|c|c|c|}
\hline Causes of maldigestion & Related diseases & Impact \\
\hline Digestive enzyme deficiency & Chronic pancreatitis, cystic fibrosis, pancreatic carcinoma & Hydrolysis of proteins, carbohydrates and fats \\
\hline Digestive enzyme inactivation by excess of $\mathrm{HCl}$ & Zollinger-Ellison syndrome & \\
\hline $\begin{array}{l}\text { Dissynchrony of enzyme release and inadequate } \\
\text { mixing }\end{array}$ & $\begin{array}{l}\text { Hyperthyroidism, post billroth ii procedure } \\
\text { (gastrojejunostomy), } \\
\text { gastric bypass }\end{array}$ & \\
\hline Diminished bile salt synthesis & Cirrhosis & Fat solubilisation Fat soluble vitamins \\
\hline Impaired bile secretion & Cystic fibrosis, chronic cholestasis & absorption \\
\hline Increased bile salt loss & Ileal disease or resection & \\
\hline Bile salt de-conjugation & Bacterial: overgrowth & \\
\hline Bacterial consumption of nutrients & Bacterial overgrowth associated to B12 deficiency & Bioavailability of specific nutrients \\
\hline Reduced gastric acid & Atrophic gastritis associated to B12 deficiency & \\
\hline Reduced intrinsic factor & Pernicious anemia associated to B12 deficiency & \\
\hline Cofactors deficiency & Gastric surgery & \\
\hline
\end{tabular}

One example for such a potential novel IVD model is for the community of Cystic Fibrosis (CF) patients that has over 35,000 cases registered in Europe (Colombo \& Littlewood, 2011). At least $85 \%$ of CF patients have pancreatic insufficiency, resulting in fat malabsorption and binding patients to the use of pancreatic enzyme supplements. Armand et al. (2004) studied the effect of diet on gastric lipase levels and fat digestion in children with CF and reported that gastric lipase was high in cystic fibrosis patients maintained on fat-rich diets (Armand et al., 2004). Further, Gelfond, Ma, Semler, and Borowitz (2013) measured the intestinal pH and GI transit profiles in CF patients (Gelfond et al., 2013). Based on this and other in vivo reports, the development of an IVD model of a CF patient need to focus on the unique secretion of pancreatic fluid and bile, both critical parameters in lipid digestion. Analytical studies show a 3.8-fold higher content of glycoconjugates than tauroconjugates in human aspirates (Brodlie et al., 2015). Thus, artificial bile should reflect composition and imbalances between tauro- and glycol-conjugates isomers and bile concentration should be low to reflect the decreased bile secretion $(1 \mathrm{mM})$. In respect to enzymatic activity, CF patients are pancreatic insufficient when pancreas function is below $10 \%$ than that of a healthy adult. Then, the pancreatine activity in a CF model should be 10 -fold lower than that considered in healthy adults.

Another potential IVD model to be developed is that of Gastric Bypass (GBP) patients (bariatric surgery patients). GBP surgery is one of the most common and effective treatments for morbid obesity but can also be used to address conditions such as type 2 diabetes or hypertension. Available physiological literature data on the digestive process are limited to indirect, with postprandial serum or urine measurements or scintigraphy evaluation of gastric emptying. Gastric emptying is reported to be very rapid for liquids, based on D-xylose in serum, from $18.6 \pm 6.9$ min prior to GBP to $7.9 \pm 2.7$ min after GBP (Wang et al., 2012). Extremely rapid pouch emptying was reported for water vs. whey proteins vs. olive oil as preloads $\left(30 \mathrm{~min}\right.$ ) for a liquid glucose drink ( $\mathrm{t}_{50} 3.8 \pm 0.9 \mathrm{vs}$. $4.1 \pm 0.6$ vs. $3.6 \pm 0.5 \mathrm{~min}$, respectively) and for a solid beef patty meal ( $1.6 \pm 0.7$ vs. $1.1 \pm 0.6$ vs. $1.3 \pm 0.5 \mathrm{~min}$, respectively) (Nguyen et al., 2016). Bojsen-Moller et al. (2015) observed accelerated caseinate digestion and amino acid absorption ( $\mathrm{C}^{13}$ leucine), resulting in faster and higher but more transient postprandial elevation of plasma amino acids. Overall, the incidence of a dumping syndrome, defined as a rapid gastric emptying, is also elevated after GBP (Horowitz, Collins, Harding, \& Shearman, 1985).

Sleeve Gastrectomy (SG), whereby the stomach duodenum connection remains intact but the volume of the stomach is drastically reduced, has been also been used as an option for surgical treatment of obesity. In such patients, gastric emptying half times $\left(t_{50}\right)$ were reported to be drastically reduced for both liquids and solids food (SG vs. control group: $34.9 \pm 24.6$ vs. $13.6 \pm 11.9 \mathrm{~min}$ for water and $78 \pm 15.01 \mathrm{vs.} 38.3 \pm 18.77$ min for solids [egg sandwich]) (Horowitz et al., 1985). The growing body of evidence on the ramifications of GBP procedures on GI function could enable the development of a relevant IVD model. Such a model would require a short gastric phase between 30 and $60 \mathrm{~min}$, probably coupled with a higher $\mathrm{pH}$ of 3.5-4.0 compared to the $\mathrm{pH} 3.0$ used in an adult IVD model. However, without luminal data, only estimates are possible. Yet, a comprehensive effort should be done to mine the literature or conduct in vivo experiments to determine enzymatic activity of pepsin and pancreatic enzymes as well as bile compositions.

The examples of CF and GBP patients are only two possibilities for novel IVD models that can be developed and subsequently validated. Other GI conditions and abnormalities can be recreated in IVD models pending relevant in vivo data is collected or found in scientific literature. These stress out the potential of expanding the horizons of IVD models based on the rationale exploitation of medical research.

\section{Conclusion}

The current modern food production system is complex, dynamic and constantly strives to fabricate safe and nutritious food products and solutions. Amongst the various efforts, researchers and manufacturers seek to rationally process, structure and formulate foods towards healthier outcomes for the consumer. These include development of food delivery systems for protection of bioactives ingredients added to food, controlling and targeting their release in the human gastrointestinal tract and affecting various dimensions of consumer well-being, e.g. shaping the colon microbiome or inducing satiety and satiation. All of these efforts rely on understanding the underlying principles guiding food's digestive fate. An understanding, which can be significantly advanced thanks to the soaring number of studies using in vitro and in vivo digestion models.

As part of the food-health revolution and evolution of food manufacturing towards tailored and personalized foods, the potential of IVD models could be maximized when extended to recreate various strata of the human population. The development of IVD models should rely on better and extensive understanding of in vivo digestion conditions in different groups of the population but would offer better opportunities to develop relevant products with high bioefficacy. Evidently, such novel tools for food and nutritional research would necessitate adequate standardization and validation to ensure synchronization of efforts and success. Such efforts would also greatly benefit from the deposition and gathering of relevant information in a database where food and health care professionals could upload in vivo data or in vivo in vitro correlations and put together pieces of puzzles needed in the 
development of new IVD models. In light of the concern over rising prevalence of chronic diseases and challenges in feeding the world, nutritional management of health and disease prevention are challenges at the footsteps of dedicated professionals. The authors of this paper hope that it will stimulate relevant progress in the field and help orchestrate global efforts towards the shared goal of advancing food science and technology.

\section{References}

Abrahamse, E., Minekus, M., van Aken, G. A., van de Heijning, B., Knol, J., et al (2012). Development of the digestive system-experimental challenges and approaches of infant lipid digestion. Food Digestion, 3, 63-77.

Aken, G. A. V., Vingerhoeds, M. H., \& Wijk, R. A. D. (2011). Textural perception of liquid emulsions: Role of oil content, oil viscosity and emulsion viscosity. Food Hydrocolloids, 25, 789-796.

Albenberg, L. G., \& Wu, G. D. (2014). Diet and the intestinal Microbiome: Associations, functions, and implications for health and disease. Gastroenterology, 146 1564-1572.

Aps, J. K. M., \& Martens, L. C. (2005). Review: The physiology of saliva and transfer of drugs into saliva. Forensic Science International, 150, 119-131.

Armand, M., Hamosh, M., Mehta, N. R., Angelus, P. A., Philpott, J. R., Henderson, T. R. et al. (1996). Effect of human milk or formula on gastric function and fat digestion in the premature Infant1. Pediatric Research, 40, 429-437.

Armand, M., Hamosh, M., Philpott, J. R., Resnik, A. K., Rosenstein, B. J., Hamosh, A. et al. (2004). Gastric function in children with cystic fibrosis: Effect of diet on gastric lipase levels and fat digestion. Pediatric Research, 55, 457-465.

Arrieta, M.-C., Stiemsma, L. T., Amenyogbe, N., Brown, E. M., \& Finlay, B. (2014). The intestinal microbiome in early life: Health and disease. Frontiers Immunology, 5 , 3389.

Blanquet, S., Zeijdner, E., Beyssac, E., Meunier, J. P., Denis, S., Havenaar, R., et al. (2004). A dynamic artificial gastrointestinal system for studying the behavior of orally administered drug dosage forms under various physiological conditions. Pharmaceutical Research, 21, 585-591.

Boivin, M., Lanspa, S. J., Zinsmeister, A. R., Go, V. L. W., \& Dimagno, E. P. (1990). Are diets associated with different rates of human interdigestive and postprandial pancreatic-enzyme secretion. Gastroenterology, 99, 1763-1771.

Bojsen-Moller, K. N., Jacobsen, S. H., Dirksen, C., Jorgensen, N. B., Reitelseder, S., Jensen, J.-E. B., et al. (2015). Accelerated protein digestion and amino acid absorption after Roux-en-Y gastric bypass. American Journal of Clinical Nutrition, 102, 600-607.

Bornhorst, G. M., Gouseti, O., Wickham, M. S. J., \& Bakalis, S. (2016). Engineering Digestion: Multiscale processes of food digestion. Journal of Food Science, 81 R534-R543.

Bourlieu, C., Ménard, O., Bouzerzour, K., Mandalari, G., Macierzanka, A., Mackie, A. R., et al. (2014). Specificity of infant digestive conditions: Some clues for developing relevant in vitro models. Critical Reviews in Food Science and Nutrition, 54, 1427-1457.

Braganza, J. M., Herman, K., Hine, P., Kay, G., \& Sandle, G. I. (1978). Gut, 19, 358-366.

Brodlie, M., Aseeri, A., Lordan, J. L., Robertson, A. G. N., McKean, M. C., Corris, P. A. et al. (2015). Bile acid aspiration in people with cystic fibrosis before and after lung transplantation. European Respiratory Journal, 46, 1820-1823.

Campbell, I. (2015). The mouth, stomach and intestines. Anaesthesia and Intensive Care Medicine, 16, 37-39.

Chatterton, D. E. W., Rasmussen, J. T., Heegaard, C. W., Sorensen, E. S., \& Petersen, T. E. (2004). In vitro digestion of novel milk protein ingredients for use in infant formulas: Research on biological functions. Trends in Food Science \& Technology, 15, 373-383.

Christian, M., Edwards, C., \& Weaver, L. T. (1999). Starch digestion in infancy. Journa of pediatric gastroenterology and nutrition, 29, 116-124.

Cinquin, C., Le Blay, G., Fliss, I., \& Lacroix, C. (2004). Immobilization of infant feca microbiota and utilization in an in vitro colonic fermentation model. Microbia Ecology, 48, 128-138.

Cinquin, C., Le Blay, G., Fliss, I., \& Lacroix, C. (2006a). Comparative effects of exopolysaccharides from lactic acid bacteria and fructo-oligosaccharides on infant gut microbiota tested in an in vitro colonic model with immobilized cells. FEMS microbiology ecology, 57, 226-238.

Cinquin, C., Le Blay, G., Fliss, I., \& Lacroix, C. (2006b). New three-stage in vitro mode for infant colonic fermentation with immobilized fecal microbiota. FEMS microbiology ecology, 57, 324-336.

Clemente, J. C., Ursell, L. K., Parfrey, L. W., \& Knight, R. (2012). The impact of the gut microbiota on human Health: An integrative view. Cell, 148, 1258-1270.

Colombo, C., \& Littlewood, J. (2011). The implementation of standards of care in Europe: State of the art. Journal of Cystic Fibrosis, 10, S7-S15.

Cummings, J. H., Pomare, E. W., Branch, W. J., Naylor, C. P., \& Macfarlane, G. T. (1987) Short chain fatty acids in human large intestine, portal, hepatic and venous blood. Gut, 28, 1221-1277.

Cummings, J. H., Banwell, J. G., Segal, I., Coleman, N., Englyst, H. N., \& Macfarlane, G. T. (1990). The amount and composition of large bowl contents in man. Gastroenterology, 98.

D'Argenio, V., Precone, V., Casaburi, G., Miele, E., Martinelli, M., Staiano, A., et al. 2013). An altered gut microbiome profile in a child affected by Crohn's diseas normalized after nutritional therapy. The American Journal of Gastroenterology, $108,851-852$.

Dall'Asta, C., Florio, P., Lammardo, A. M., Prandi, B., Mazzeo, T., Budelli, A., et al. (2015). Development of an in vitro digestive model for studying the peptide profile of breast milk. International Journal of Food Sciences and Nutrition, 66, 409-415.

Deat, E., Blanquet-Diot, S., Jarrige, J.-F., Denis, S., Beyssac, E., \& Alric, M. (2009). Combining the dynamic TNO-gastrointestinal tract system with a Caco-2 cell culture Model: Application to the assessment of lycopene and alpha-tocopherol bioavailability from a whole food. Journal of Agricultural and Food Chemistry, 57, $11314-11320$.

Dekkers, B. L., Kolodziejczyk, E., Acquistapace, S., Engmann, J., \& Wooster, T. J. (2016). Impact of gastric pH profiles on the proteolytic digestion of mixed [small beta]lg-Xanthan biopolymer gels. Food \& Function, 7, 58-68.

Denis, S., Sayd, T., Georges, A., Chambon, C., Chalancon, S., sante-lhoutellier, V., et al. (2016 Jun 15). Digestion of cooked meat proteins is slightly affected by age conditions as assessed using the dynamic gastrointestinal TIM model and mass spectrometry. Food \& Function, 7(6), 2682-2691.

DeSesso, J. M., \& Jacobson, C. F. (2001). Anatomical and physiological parameters affecting gastrointestinal absorption in humans and rats. Food and Chemical Toxicology, 39, 209-228.

Di Francesco, V., Zamboni, M., Dioli, A., Zoico, E., Mazzali, G., Omizzolo, F., et al. (2005). Delayed postprandial gastric emptying and impaired gallbladder contraction together with elevated cholecystokinin and peptide YY serum levels sustain satiety and inhibit hunger in healthy elderly persons. Journals of Gerontology Series a-Biological Sciences and Medical Sciences, 60, 1581-1585.

Dressman, J. B., Berardi, R. R., Dermentzoglou, L. C., Russell, T. L., Schmaltz, S. P., Barnett, J. L., et al. (1990). Upper GI pH in young, healthy-men and women. Pharmaceutical Research, 7, 756-761.

Dupont, D., Mandalari, G., Molle, D., Jardin, J., Leonil, J., Faulks, R. M., et al. (2010a). Comparative resistance of food proteins to adult and infant in vitro digestion models. Molecular Nutrition \& Food Research, 54, 767-780.

Dupont, D., Mandalari, G., Mollé, D., Jardin, J., Rolet-Répécaud, O., Duboz, G., et al. (2010b). Food processing increases casein resistance to simulated infant digestion. Molecular nutrition \& food research, 54, 1677-1689.

Edginton, A. N., \& Fotaki, N. (2010). Oral drug absorption in pediatric populations. Oral drug absorption: Prediction and assessment. 2nd edn. New York: Informa Healthcare, 108-126.

Egger, L., Ménard, O., Delgado-Andrade, C., Alvito, P., Assunção, R., Balance, S., et al. (2016). The harmonized INFOGEST in vitro digestion method: From knowledge to action. Food Research International.

Ekmekcioglu, C. (2002). A physiological approach for preparing and conducting intestinal bioavailability studies using experimental systems. Food Chemistry, $76,225-230$.

Elashoff, J. D., Reedy, T. J., \& Meyer, J. H. (1982). Analysis of gastric-emptying data. Gastroenterology, 83, 1306-1312.

Evans, D. F., Pye, G., Bramley, R., Clark, A. G., Dyson, T. J., \& Hardcastle, J. D. (1988). Measurement of gastrointestinal pH profiles in normal ambulant human subjects. Gut, 29, 1035-1041.

Fausa, O. (1974). Duodenal Bile acids after a test meal. Scandinavian Journal of Gastroentereology, 9, 567-570.

Feldman, M., Cryer, B., McArthur, K. E., Huet, B. A., \& Lee, E. (1996). Effects of aging and gastritis on gastric acid and pepsin secretion in humans: A prospective study. Gastroenterology, 110, 1043-1052.

Ferrua, M. J., \& Singh, R. P. (2010). Modeling the fluid dynamics in a human stomach to gain insight of food digestion. Journal of Food Science, 75, R151-R162.

Flint, H. J. (2012). The impact of nutrition on the human microbiome. Nutrition Reviews, 70, S10-S13.

Floros, J. D., Newsome, R., Fisher, W., Barbosa-Cánovas, G. V., Chen, H., Dunne, C. P., et al. (2010). Feeding the World Today and Tomorrow: The Importance of Food Science and Technology. Comprehensive Reviews in Food Science and Food Safety, 9, 572-599.

Fogleman, A. D., Cohen, R. S., Sakamoto, P., \& Allen, J. C. (2012). Addition of calcium and phosphorus to preterm donor human milk and the impact on protein, fat, and calcium digestibility in vitro. ICAN: Infant. Child, \& Adolescent Nutrition, 4 199-206.

Gelfond, D., Ma, C., Semler, J., \& Borowitz, D. (2013). Intestinal pH and gastrointestinal transit profiles in cystic fibrosis patients measured by wireless motility capsule. Digestive diseases and sciences, 58, 2275-2281.

Glahn, R. P., Wien, E. M., VanCampen, D. R., \& Miller, D. D. (1996). Caco-2 cell iron uptake from meat and casein digests parallels in vivo studies: Use of a novel in vitro method for rapid estimation of iron bioavailability. Journal of Nutrition, $126,332-339$.

Gotch, F., Nadell, J., \& Edelman, I. S. (1957). Gastrointestinal water and electrolytes. Journal of Clinical Investigation, 36, 289-296.

Grundy, M. M. L., Edwards, C. H., Mackie, A. R., Gidley, M. J., Butterworth, P. J., \& Ellis, P. R. (2016). Re-evaluation of the mechanisms of dietary fibre and implications for macronutrient bioaccessibility, digestion and postprandial metabolism. British Journal of Nutrition, 816-833.

Guerra, A., Etienne-Mesmin, L., Livrelli, V., Denis, S., Blanquet-Diot, S., \& Alric, M. (2012). Relevance and challenges in modeling human gastric and small intestinal digestion. Trends in Biotechnology, 30, 591-600.

Guyton, A. C. (1991). Textbook of medical physiology. Philadelphia, USA: W.B. Saunders Company, 793-779.

Hamosh, M. (1994). Gastric and lingual lipases. 
Hamosh, M. (2006). Enteral lipid digestion and absorption. Neonatal nutrition and metabolism, 350-367.

Havenaar, R., Anneveld, B., Hanff, L. M., de Wildt, S. N., de Koning, et al. (2013), In vitro gastrointestinal model (TIM) with predictive power, even for infants and children? International journal of pharmaceutics, 457, 327-332.

Henderson, T. R., Hamosh, M., Armand, M., Mehta, N. R., \& Hamosh, P. (1998), Gastric proteolysis in the preterm Infant: Protein digestion is limited and is not affected by diet, human milk or formula $\dagger$ 580. Pediatric Research, 43, 101-101.

Hofmann, A. F. (1999). The continuing importance of bile acids in liver and intestinal disease. Archives of Internal Medicine, 159, 2647-2658.

Högenhauer, C., \& Hammer, H. F. (2010). Maldigestion and malabsorption (9 ed.). Philadelphia: WB Saunders.

Holmes, R., \& Lobley, R. W. (1989). Intestinal brush-border revisited. Gut, 30, 1667-1678.

Holscher, H. D., Caporaso, J. G., Hooda, S., Brulc, J. M., Fahey, G. C., Jr., \& Swanson, K. S. (2015). Fiber supplementation influences phylogenetic structure and functional capacity of the human intestinal microbiome: Follow-up of a randomized controlled trial. American Journal of Clinical Nutrition, 101, 55-64.

Holtmann, G., Kelly, D. G., \& DiMagno, E. P. (1996). Nutrient and cyclical interdigestive pancreatic enzyme secretion in humans. Gut, 38, 920-924.

Horowitz, M., Collins, P., Harding, P., \& Shearman, D. (1985). Gastric emptying after gastric bypass. International Journal of Obesity, 10, 117-121.

Houghton, L. A., Hickson, F., \& Read, N. W. (1987). Effect of food consistency on gastric emptying in man. Gut, 28, 1584-1588.

Hunt, J. N. (1951). The secretory pattern of the stomach of man. The Journal of Physiology, 113(2-3), 169-184.

Hur, S. J., Lim, B. O., Decker, E. A., \& McClements, D. J. (2011). In vitro human digestion models for food applications. Food Chemistry, 125, 1-12.

Bruce, J. (2012). Digestion of protein in premature and term infants. Journal of Nutritional Disorders \& Therapy.

Janowitz, H. D., \& Hollander, F. (1952). The basal secretion of pepsin by the human stomach. Journal of Clinical Investigation, 31(3), 338-340.

Johnson, L. R. (2007). Gastrointestinal phsiology (7th ed.). Philadelphia: Mosby Elsevier.

Johnston, N., Dettmar, P. W., Bishwokarma, B., Lively, M. O., \& Koufman, J. A. (2007). Activity/stability of human pepsin: Implications for reflux attributed laryngeal disease. Laryngoscope, 117, 1036-1039.

Joost, H.-G., Gibney, M. J., Cashman, K. D., Gorman, U., Hesketh, J. E., Mueller, M., et al. (2007). Personalised nutrition: Status and perspectives. British Journal of Nutrition, 98, 26-31.

Kalantzi, L., Goumas, K., Kalioras, V., Abrahamsson, B., Dressman, J. B., \& Reppas, C. (2006). Characterization of the human upper gastrointestinal contents under conditions simulating bioavailability/bioequivalence studies. Pharmaceutical Research, 23, 165-176.

Keller, J., \& Layer, P. (2005). Human pancreatic exocrine response to nutrients in health and disease. Gut, 54, 1-28.

Kelly, D., \& Coutts, A. G. P. (2000). Development of digestive and immunological function in neonates: Role of early nutrition. Livestock Production Science, 66, $161-167$.

Kelly, E. J., \& Newell, S. J. (1994). Gastric Ontogeny - clinical implications. Archives of Disease in Childhood, 71, F136-F141.

Kong, F. B., \& Singh, R. P. (2010a). A human gastric simulator (HGS) to study food digestion in human stomach. Journal of Food Science, 75, E627-E635.

Kong, F. B., \& Singh, R. P. (2010b). Solid loss of carrots during simulated gastric digestion. Food Biophysics, 6, 84-93.

Kopf-Bolanz, K. A., Schwander, F., Gijs, M., Vergeres, G., Portmann, R., \& Egger, L. (2012). Validation of an in vitro digestive system for studying macronutrient decomposition in humans. Journal of Nutrition, 142, 245-250.

Krogdahl, A., \& Holm, H. (1979). Inhibition of human and rat pancratic proteinases by crude and purified soybean proteinase inhibitors. Journal of Nutrition, 109, $551-558$.

Laugier, R., Bernard, J. P., Berthezene, P., \& Dupuy, P. (1991). Changes in pancreatic exocrine secretion with age - pancreatic exocrine secretion does decrease in the elderly. Digestion, 50, 202-211.

Lebenthal, E., \& Lee, P. (1980). Development of functional response in human exocrine pancreas. Pediatrics, 66, 556-560.

Lebenthal, E., Lee, P., \& Heitlinger, L. A. (1983). Impact of development of the gastrointestinal tract on infant feeding. The Journal of pediatrics, 102, 1-9.

Lefebvre, D. E., Venema, K., Gombau, L., Valerio, L. G., Jr., Raju, J., Bondy, G. S., et al. (2015). Utility of models of the gastrointestinal tract for assessment of the digestion and absorption of engineered nanomaterials released from food matrices. Nanotoxicology, 9, 523-542.

Levi, C. S., \& Lesmes, U. (2014). Bi-compartmental elderly or adult dynamic digestion models applied to interrogate protein digestibility. Food \& Function, 5, 2402-2409.

Li-Chan, E., \& Nakai, S. (1989). Enzymic dephosphorylation of bovine casein to improve acid clotting properties and digestibility for infant formula. Journal of Dairy Research, 56, 381-390.

Lindquist, S., \& Hernell, O. (2010). Lipid digestion and absorption in early life: An update. Current Opinion in Clinical Nutrition \& Metabolic Care, 13, 314-320.

Liu, D., Wang, Y., Yu, Y., Hu, J., Lu, N., Regenstein, J. M., et al. (2016). Effects of enzymatic dephosphorylation on infant in vitro gastrointestinal digestibility of milk protein concentrate. Food Chemistry, 197, 891-899.

Lueamsaisuk, C., Lentle, R. G., MacGibbon, A. K. H., Matia-Merino, L., \& Golding, M. (2014). Factors influencing the dynamics of emulsion structure during neonatal gastric digestion in an in vitro model. Food Hydrocolloids, 36, 162-172.

Lueamsaisuk, C., Lentle, R. G., MacGibbon, A. K. H., Matia-Merino, L., \& Golding, M. (2015). The effect of lactoferrin on physical changes in phospholipid stabilised emulsions during neonatal in vitro gastric digestion: Does synergism of pepsin and lipase promote lipolysis in protein-stabilised emulsions? Food Hydrocolloids, 43, 785-793.

Macfarlane, G. T., Macfarlane, S., \& Gibson, G. R. (1998). Validation of a three-stage compound continuous culture system for investigating the effect of retention time on the ecology and metabolism of bacteria in the human colon. Microbial Ecology, 35, 180-187.

Malagelada, J. R., Longstreth, G. F., Summerskill, W. H. J., \& Go, V. W. (1976). Measurement of gastric functions during digestion of ordinary solid meals in man. Gastroenterology, 70, 203-210.

Manione, G., Nitride, C., Picariello, G., Addeo, F., Ferranti, P., \& Mackie, A. (2015). Tracking the fate of pasta (T. Durum semolina) immunogenic proteins by in vitro simulated digestion. Journal of Agricultural and Food Chemistry, 63, 2660-2667.

Matamoros, S., Gras-Leguen, C., Le Vacon, F., Potel, G., \& de La Cochetiere, M.-F. (2013). Development of intestinal microbiota in infants and its impact on health. Trends in microbiology, 21, 167-173.

McClements, D. J., \& Li, Y. (2010). Review of in vitro digestion models for rapid screening of emulsion-based systems. Food \& Function, 1, 32-59.

Menard, O., Cattenoz, T., Guillemin, H., Souchon, I., Deglaire, A., Dupont, D., et al. (2014). Validation of a new in vitro dynamic system to simulate infant digestion. Food Chemistry, 145, 1039-1045.

Ménard, D., Monfils, S., \& Tremblay, E. (1995). Ontogeny of human gastric lipase and pepsin activities. Gastroenterology, 108, 1650-1656.

Mercuri, A., Lo Curto, A., Wickham, M. S. J., Craig, D. Q. M., \& Barker, S. A. (2008). Dynamic gastric model (DGM): A novel in vitro apparatus to assess the impact of gastric digestion on the droplet size of self-emulsifying drug-delivery systems. Journal of Pharmacy and Pharmacology, 60, 4.

Meyer, J. H., Elashoff, J. D., \& Lake, R. (1999). Gastric emptying of indigestible versus digestible oils and solid fats in normal humans. Digestive Diseases and Sciences, 44, 1076-1082.

Miled, N., Canaan, S., Dupuis, L., Roussel, A., Riviere, M., Carriere, F., et al. (2000) Digestive lipases: From three-dimensional structure to physiology. Biochimie, 82, 973-986.

Minekus, M., Alminger, M., Alvito, P., Ballance, S., Bohn, T., Bourlieu, C., et al. (2014). A standardised static in vitro digestion method suitable for food - an international consensus. Food \& Function.

Minekus, M., Marteau, P., Havenaar, R., \& Huisintveld, J. H. J. (1995). A multicompartmental dynamic computer-controlled model simulating the stomach and small-intestine. Atla-Alternatives to Laboratory Animals, 23 197-209.

Molly, K., Woestyne, M. V., \& Verstraete, W. (1993). Development of A 5-step multichamber reactor as a simulation of the human intestinal microbial ecosystem. Applied Microbiology and Biotechnology, 39, 254-258.

Moran, B. J., \& Jackson, A. A. (1992). Function of the human colon. British Journal of Surgery, 79, 1132-1137.

Nagler, R. M., \& Hershkovich, O. (2005). Relationships between age, drugs, oral sensorial complaints and salivary profile. Archives of Oral Biology, 50, 7-16.

Nardone, G., \& Malfertheiner, P. (2011). Gut Microbiota: The Forgotten Organ Preface. Digestive Diseases, 29, 517-517.

Neyraud, E., Palicki, O., Schwartz, C., Nicklaus, S., \& Feron, G. (2012). Variability of human saliva composition: Possible relationships with fat perception and liking. Archives of Oral Biology, 57, 556-566.

Nguyen, T. T., Bhandari, B., Cichero, J., \& Prakash, S. (2015a). A comprehensive review on in vitro digestion of infant formula. Food Research International, 76, $373-386$.

Nguyen, T. T., Bhandari, B., Cichero, J., \& Prakash, S. (2015b). Gastrointestinal digestion of dairy and soy proteins in infant formulas: An in vitro study. Food Research International, 76, 348-358.

Nguyen, N. Q., Debreceni, T. L., Burgstad, C. M., Neo, M., Bellon, M., Wishart, J. M., et al. (2016). Effects of Fat and Protein Preloads on Pouch Emptying, Intestinal Transit, Glycaemia, Gut Hormones, Glucose Absorption, Blood Pressure and Gastrointestinal Symptoms After Roux-en-Y Gastric Bypass. Obesity Surgery, 26, $77-84$.

Nolan, J. D., Johnston, I. M., \& Walters, J. R. (2012). Physiology of malabsorption. Surgery (Oxford), 30, 268-274.

Ogden, J. M., O’Keefe, S. J. D., Louw, J. A., Adams, G., \& Marks, I. N. (1993). Duodenal juice total protein and pancreatic enzyme synthesis, turnover, and secretion in patients after acute pancreatitis. Gut, 34, 1261-1266.

O'Hara, A. M., \& Shanahan, F. (2006). The gut flora as a forgotten organ. EMBO Rep, 7, 688-693.

O'Keefe, S. J. D., Lee, R. B., Anderson, F. P., Gennings, C., Abou-Assi, S., Clore, J., et al. (2003). Physiological effects of enteral and parenteral feeding on pancreaticobiliary secretion in humans. American Journal of PhysiologyGastrointestinal and Liver Physiology, 284, G27-G36.

de Oliveira, S. C., Deglaire, A., Ménard, O., Bellanger, A., Rousseau, F., et al. (2015). Holder pasteurization impacts the proteolysis, lipolysis and disintegration of human milk under in vitro dynamic term newborn digestion. Food Research International.

Olszewska, J., \& Jagusztyn-Krynicka, E. K. (2012). Human Microbiome Project - influence of gut microbiota on human physiology and health. Postepy Mikrobiologii, 51, 243-256. 
Payne, A. N., Zihler, A., Chassard, C., \& Lacroix, C. (2012). Advances and perspectives in in vitro human gut fermentation modeling. Trends in Biotechnology, 30, $17-25$.

Power-Grant, O., McCormack, W. G. D. E., Cap, M. R., Amigo-Benavent, M. Fitzgerald, R. J., et al. (2016). Evaluation of the antioxidant capacity of a milk protein matrix in vitro and in vivo in women aged 50-70 years. Internationa Journal of Food Sciences and Nutrition, 67, 325-334.

Prakash, S., Ma, Q., \& Bhandari, B. (2014). Rheological behaviour of selected commercially available baby formulas in simulated human digestive system. Food Research International, 64, 889-895.

Qi, L. (2014). Personalized nutrition and obesity. Annals of Medicine, 46, 247-252.

Rantonen, P. (2003). Salivary flow and composition in healthy and diseased adults. Helsinki: University of Helsinki. Unpublished PhD Thesis.

Remond, D., Shahar, D. R., Gille, D., Pinto, P., Kachal, J., Peyron, M. A., et al. (2015). Understanding the gastrointestinal tract of the elderly to develop dietary solutions that prevent malnutrition. Oncotarget, 6, 13858-13898.

Roberts, N. B. (2006). Review article: Human pepsins - their multiplicity, function and role in reflux disease. Alimentary Pharmacology and Therapeuthics, 24(Suppl. 2), 2-9.

Roman, C., Carriere, F., Villeneuve, P., Pina, M., Millet, V., Simeoni, U., et al. (2007) Quantitative and qualitative study of gastric lipolysis in premature infants: Do MCT-enriched infant formulas improve fat digestion? Pediatric Research, 61, 83-88.

Romano, A., Giosafatto, C. V. L., Di Pierro, P., Romano, R., Masi, P., \& Mariniello, L. (2016). Impact of transglutaminase on properties and in vitro digestibility of white bean (Phaseolus vulgaris L.) flour. Food Research International, 88, 239-246.

Romano, A., Giosafatto, C., Masi, P., \& Mariniello, L. (2015). Impact of dehulling on the physico-chemical properties and in vitro protein digestion of common beans (Phaseolus vulgaris L.). Food Function, 6, 1345-1351.

Roussel, C., Cordonnier, C., Wessam, G., Le Goff, O., Thévenot, J., Chalancon, S., Alric, M., et al. (2016 Nov). Increased EHEC survival and virulence gene expression indicate an enhanced pathogenesis upon simulated infant gastrointestinal conditions. Pediatric Research, 80(5), 734-743.

Russell, T. L., Berardi, R. R., Barnett, J. L., Dermentzoglou, L. C., Jarvenpaa, K. M., Schmaltz, S. P., et al. (1993). Upper gastrointestinal PH in 79 healthy, elderly, north-american men and women. Pharmaceutical Research, 10, 187-196.

Salles, N. (2007). Basic mechanisms of the aging gastrointestinal tract. Digestive Diseases, 25, 112-117.

Sams, L., Paume, J., Giallo, J., \& Carriere, F. (2016). Relevant pH and lipase for in vitro models of gastric digestion. Food \& Function, 7, 30-45.

Sarkar, A., Goh, K. K. T., \& Singh, H. (2009). Colloidal stability and interactions of milk-protein-stabilized emulsions in an artificial saliva. Food Hydrocolloids, 23 $1270-1278$.

Sarkar, A., Goh, K. K. T., \& Singh, H. (2010). Properties of oil-in-water emulsions stabilized by beta-lactoglobulin in simulated gastric fluid as influenced by ionic strength and presence of mucin. Food Hydrocolloids, 24, 534-541.

Sarles, J., Moreau, H., \& Verger, R. (1992). Human gastric lipase: Ontogeny and variations in children. Acta Paediatrica, 81, 511-513.

Sarosiek, I., Selover, K. H., Katz, L. A., Semler, J. R., Wilding, G. E., Lackner, J. M., et al 2010). The assessment of regional gut transit times in healthy controls and patients with gastroparesis using wireless motility technology. Alimentary Pharmacology \& Therapeutics, 31, 313-322.

Schlamowitz, M., \& Peterson, L. U. (1959). Studies on the optimum pH for the action of pepsin on" native" and denatured bovine serum albumin and bovine hemoglobin. Journal of Biological Chemistry, 234, 3137-3145.
Seeley, R. R., Stephens, T. D., \& Tate, P. (1992). Anatomy and physiology.

Sensoy, I. (2014). A review on the relationship between food structure, processing and bioavailability. Critical Reviews in Food Science and Nutrition, 54, 902-909.

Sevenhuysen, G. P., Holodinsky, C., \& Dawes, C. (1984). Development of salivary alpha-amylase in infants from birth to 5 months. The American journal of clinical mutrition, 39, 584-588.

Shani-Levi, C., Levi-Tal, S., \& Lesmes, U. (2013). Comparative performance of milk proteins and their emulsions under dynamic in vitro adult and infant gastric digestion. Food Hydrocolloids, 32, 349-357.

Shern, R. J., Fox, P. C., \& Li, S. H. (1993). Influence of age on the secretory rates of the human minor salivary glands and whole saliva. Archives of Oral Biology, 38, 755-761.

Singh, H., \& Ye, A. Q. (2013). Structural and biochemical factors affecting the digestion of protein-stabilized emulsions. Current Opinion in Colloid \& Interface Science, 18, 360-370.

Tharakan, A., Norton, I. T., Fryer, P. J., \& Bakalis, S. (2010). Mass transfer and nutrient absorption in a simulated model of small intestine. Journal of Food Science, 75 E339-E346.

Tortora, G. J., \& Derrickson, B. (2011). Principles of anatomy and physiology (13th ed., Vol. 2). Hoboken: Wiley and Sons Inc.

Turnbaugh, P. J., Ley, R. E., Hamady, M., Fraser-Liggett, C. M., Knight, R., \& Gordon, J. I. (2007). The human microbiome project. Nature, 449, 804-810.

Ulleberg, E., Comi, I., Holm, H., Herud, E., Jacobsen, M., \& Vegarud, G. (2011). Human gastrointestinal juices intended for use in in vitro digestion models. Food Digestion, 2, 52-61.

UN. (2013). World population ageing 2013. In: United nations,

Vellas, B., Balas, D., Moreau, J., Bouisson, M., Senegasbalas, F., Guidet, M., et al (1988). Exocrine pancreatic-secretion in the elderly. International Journal of Pancreatology, 3, 497-502.

Versantvoort, C. H. M., Van de Kamp, E., \& Rompelberg, C. J. M. (2004). Development and applicability of an in vitro digestion model in assessing the bioaccessibility of contaminants from food. In Bilthoven. The Netherlands: National Institute for Public Health and the Environment.

Vingerhoeds, M. H., Silletti, E, de Groot, J Schipper, R. G. \& van Aken, G. A. (2009). Relating the effect of saliva-induced emulsion flocculation on rheological properties and retention on the tongue surface with sensory perception. Food Hydrocolloids, 23, 773-785.

van Vliet, T., van Aken, G. A., de Jongh, H. H. J., \& Hamer, R. J. (2009). Colloidal aspects of texture perception. Advances in Colloid and Interface Science, 150, 27-40.

Vors, C., Capolino, P., Guerin, C., Meugnier, E., Pesenti, S., Chauvin, M. A., et al. (2012). Coupling in vitro gastrointestinal lipolysis and Caco-2 cell cultures for testing the absorption of different food emulsions. Food \& Function, 3, 537-546.

Wada, Y., \& Loennerdal, B. (2014). Effects of different industrial heating processes of milk on site-specific protein modifications and their relationship to in vitro and in vivo digestibility. Journal of Agricultural and Food Chemistry, 62, 4175-4185.

Wada, Y., \& Loennerdal, B. (2015). Bioactive peptides released from in vitro digestion of human milk with or without pasteurization. Pediatric Research, 77, $546-553$.

Wang, G., Agenor, K., Pizot, J., Kotler, D. P., Harel, Y., Van Der Schueren, B. J., et al. (2012). Accelerated gastric emptying but No carbohydrate malabsorption 1 Year after gastric bypass surgery (GBP). Obesity Surgery, 22, 1263-1267.

Yoo, J. Y., \& Chen, X. D. (2006). Git physicochemical modeling - a critical review. International Journal of Food Engineering, 2.

Zeevi, D., Korem, T., Zmora, N., Israeli, D., Rothschild, D., Weinberger, A., et al. (2015). Personalized nutrition by prediction of glycemic responses. Cell, 163, 1079-1094. 